\title{
Thermo- and pH-Responsive Poly(A-ProOMe)-graft-poly(AAc) Membrane for Selective Separation of Metal Ions
}

\author{
By Shin HASEGAWA, ${ }^{1,2, *}$ Hitoshi OHASHI, ${ }^{2}$ Yasunari MAEKAWA, ${ }^{1}$ \\ Ryoichi KATAKAI, ${ }^{2}$ and Masaru YOSHIDA ${ }^{1}$
}

We investigated the permeation behavior of $\mathrm{Li}, \mathrm{Co}$, and $\mathrm{Ni}$ ions through thermo- and $\mathrm{pH}$-responsive gel membranes, which were prepared by $\gamma$-ray grafting of $\mathrm{pH}$-responsive poly(acrylic acid) (poly(AAc)) onto a thermo-responsive polymer gel of acryloyl-L-proline methyl ester (A-ProOMe). Using 15\% AAc grafted membranes, the permeation constants of Li ions are 2.8 and 3.5 times higher than those of $\mathrm{Co}$ and $\mathrm{Ni}$ ions in a $\mathrm{pH} 6.0$ buffer solution at $30^{\circ} \mathrm{C}$. These ratios are two and three times higher than those of 5 and $43 \%$ grafted gel membranes, respectively. By comparison with the permeation of metal ions through the non-thermo-responsive porous polyethylene membranes grafted with AAc chains or random copolymer gel membranes (poly(A-ProOMe-co-AAc)), it is clear that the structure in which adjacent carboxyl groups of poly(AAc) are surrounded by thermo-responsive A-ProOMe matrix causes selective permeability of $\mathrm{Li}$ ion over $\mathrm{Co}$ and $\mathrm{Ni}$ ions. The distributions of $\mathrm{Co}$ and $\mathrm{Ni}$ ions in the microscopic structures clearly show that the structure consisting of flexible chains of the carboxyl groups grafted onto the thermo-response gel membrane plays a decisive role in the superior selective permeation of a $\mathrm{Li}$ ion.

KEY WORDS: Gel / Graft / Polymerization / Radiation / Metal / Permeation /

In recent years, there have been a plenty of attempts for developing environmentally responsive gels, which undergo discontinuous and reversible volume phase transitions in response to external stimuli such as temperature, $\mathrm{pH}$, electric fields, and solvent composition, because of their potential applications in the fields of drug delivery, separation systems, chemomechanical actuators, and the like. ${ }^{1-6}$

The gel membrane can be prepared by a radiation induced polymerization method, characterized by simultaneously occurring processes of polymerization and self-crosslinking in aqueous solution. $^{7-9}$ Since these gels can be formed from monomers only without initiator, crosslinker, or accelerator, the radiation method for gel preparation can be applied, making possible the formation of a super-clean gel. In addition to gel preparation, graft copolymers consisting of both random and block structures can be easily synthesized through simultaneous or stepwise polymerization by radiation (Figure 1).

There were several reports about temperature- and $\mathrm{pH}$ responsive polymers and only temperature responsive hydrogels. ${ }^{10,11}$ However, there have not been reported about both thermo- and $\mathrm{pH}$-sensitive hydrogels to control permeation behavior of metal ions. Thus, we had reported the successful preparation of gel membranes with both thermo- and $\mathrm{pH}-$ sensitivities using the radiation technique. ${ }^{6}$

The gel membranes consisted of poly(acrylic acid) (poly(AAc) graft chains with $\mathrm{p} K_{\mathrm{a}}=4.7,{ }^{11}$ onto a poly(acryloylL-proline methyl ester (A-ProOMe)) gel membrane, which undergoes volume phase transition at around $14{ }^{\circ} \mathrm{C}$ (poly(AProOMe)-graft-poly(AAc)). ${ }^{12,13}$ The gel membrane composi- tion of which $15 \%$ is AAc graft chain exhibited volume change in response to both temperature and $\mathrm{pH}$-changes. It may be assumed that the permeability of metal ions through membranes can be controlled by changing the volume of both the hydrophobic (A-ProOMe) and hydrophilic (AAc) portions of the membrane, and thus, we attempted to use thermo- and pH-responsive membranes for selective metal separation. The preliminary results of the permeation behavior of metal ions through the gel membranes were described in our previous paper. ${ }^{6}$ However, details of metal ion permeation through the membranes such as permeation conditions, composition and micro structures of the gel membranes, and interactions with metal ions, have not been done. Thus, in this paper, we investigated the optimal molar ratio for the grafting of AAc and optimum conditions, such as temperature and $\mathrm{pH}$, for selective permeation of metal ions ( $\mathrm{Li}, \mathrm{Co}$, and $\mathrm{Ni}$ ) through the membranes. An element of lithium is one of the important materials for a lithium battery as well as the fuel element of a nuclear fusion system. Therefore, the recycling of Li ions by new membrane separation in stead of current extraction using chemical reagents should become a very environment-friendly system. Since Li, Co, and Ni ions are used for a lithium battery, we have been first attempting the separation of $\mathrm{Li}$ ions from $\mathrm{Co}$ and $\mathrm{Ni}$ ions for a basic research to establish a new element recycling system. Furthermore, the effects of thermo-responsiveness and graft chains block structure of the membrane on the selective permeation was investigated by comparing with membranes with non-thermo responsive structure (porous polyethylene) and random copolymer gel membranes. ${ }^{14}$

\footnotetext{
${ }^{1}$ Conducting Polymer Materials Group, Environment and Industrial Materials Research Division, Quantum Beam Science Directorate, Japan Atomic Energy Agency (JAEA), 1233 Watanuki, Takasaki 370-1292, Japan

${ }^{2}$ Department of Chemistry, Faculty of Engineering, Gunma University, 1-5-1 Tenjin, Kiryu 376-8515, Japan

*To whom correspondence should be addressed (Tel: +81-27-346-9410, Fax: +81-27-346-9867, E-mail: hasegawa.shin @jaea.go.jp).
} 
(a)

(b)

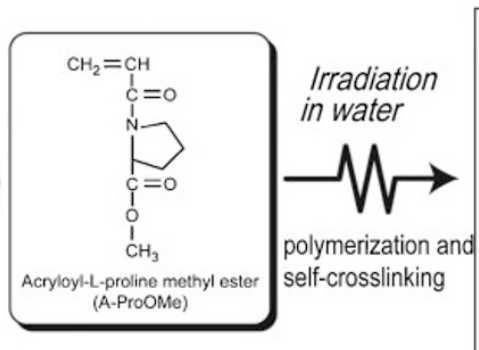

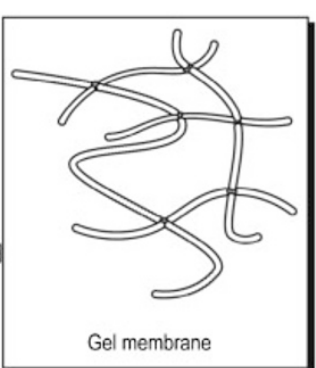

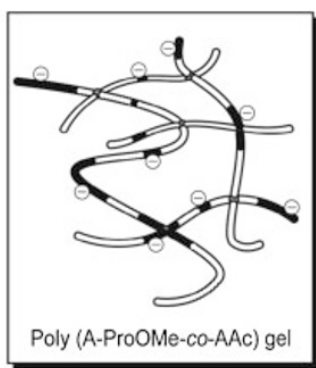

Poly (A-ProOMe-Co-AAc) ge

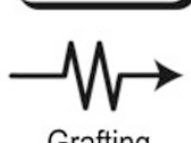

Grafting

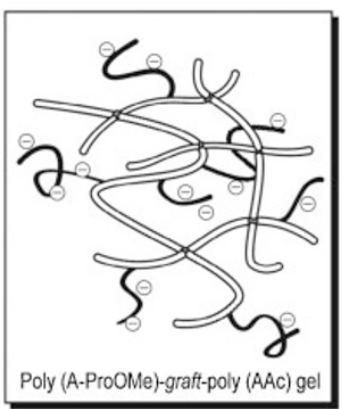

Figure 1. Schematic illustration for the synthesis of self-crosslinking random copolymer gels (a) and grafted block copolymer gels (b) using radiation technique.

\section{EXPERIMENTAL}

\section{Materials}

Acrylic acid (AAc; Kishida Chemical Co. Ltd.) was used after distillation. Distilled water (Kyoei Co Ltd.) and acetone (Wako Pure Chemical. Co., Ltd.) were used as received. Lithium chloride anhydrous purchased from Kanto Chemical Inc. and cobalt chloride and nickel chloride purchased from Wako Pure Chemical Co., Ltd. were used without further purification. Buffer solutions of $\mathrm{pH}$ 1.0-9.0 consisting of potassium hydrogen phthalate and sodium hydroxide were purchased from Wako Pure Chemical Co., Ltd. and Kanto Chemical Inc., respectively. Acryloyl-L-proline methyl ester (A-ProOMe) was synthesized as described in previous papers. ${ }^{15}$ Graft copolymer gel membranes in response to change in temperature and $\mathrm{pH}$ were prepared in the same manners as described in previous paper. ${ }^{6}$

\section{Synthesis of Copolymer Gel Membranes}

Random copolymer gel membrane of AAc/A-ProOMe was synthesized as follows (Figure 2). ${ }^{14,15}$ The $30 \mathrm{vol} . \%$ aquarium mixture of AAc/A-ProOMe mole ratio (13:2 mol) was charged into two glass plates $(50 \times 50 \times 2 \mathrm{~mm})$ that was separated by an $800 \mu \mathrm{m}$ poly(ethylene terephthalate) spacer film. The radiation-induced reaction for polymerization and crosslinking was carried out at $0{ }^{\circ} \mathrm{C}$ for $3 \mathrm{~h}$ at a dose rate of $10 \mathrm{kGy} / \mathrm{h}$, using $\gamma$-rays from a ${ }^{60} \mathrm{Co}$ source. The obtained copolymer gels were washed with excess acetone and water to remove the unreacted monomer and homopolymers, and then displaced with water.

The graft polymerization was carried out in the same manner as previous reports. ${ }^{16,17}$ The porous poly(ethylene)
(PE) films of $100 \mu \mathrm{m}$ thickness (SUN MAP LC-T (NITTO DENKO CORPORATION)) were exhaustively rinsed by Soxhlet extractor in acetone for $24 \mathrm{~h}$ at $40^{\circ} \mathrm{C}$. The PE films were dried under vacuum and then were packed in a polyethylene bag under nitrogen atmosphere. Samples placed on a stainless-steel plate were irradiated with an electron accelerator (Dynamitron, Model IEA 300-25-2, Radiation Dynamics Co.) operating at beam energy of $2.0 \mathrm{MeV}$ and a current of $1 \mathrm{~mA}$ at room temperature.

Immediately after irradiation, the porous films were placed into a glass ampoule and were evacuated. The introduction of AAc/acetone (90/10 vol. \%) to those irradiated PE films was carried out under nitrogen atmosphere. The grafting was performed at $60^{\circ} \mathrm{C}$ for $24 \mathrm{~h}$. After grafting, the porous PE films were immersed in an excess amount of acetone, and gradually replaced into a distilled-deionized water to remove unreacted monomer and homopolymers. Subsequently, the films were dried under vacuum for $24 \mathrm{~h}$. The grafting yield was calculated by the percentage increase in weight as follows:

$$
\text { Degree of grafting }(\%)=100 \times\left(W-W_{0}\right) / W_{0}
$$

where $W_{0}$ and $W$ represent the weight of initial and grafted films, respectively.

\section{The Permeability Measurement}

We measured the permeability constants $(P)$ of metal ions through thermo- and $\mathrm{pH}$-responsive gel membranes using a diffusion-type modified Franz cell. ${ }^{14,18}$ The gel membrane was cut into disks in $1.9 \mathrm{~cm}$ diameter and then set between two diffusion cells consisting of donor $(5 \mathrm{~mL})$ and receiver $(50 \mathrm{~mL})$ chambers, in which the effective film area was $2.83 \mathrm{~cm}^{2}$. On metal permeation experiments through grafted gel membranes, 


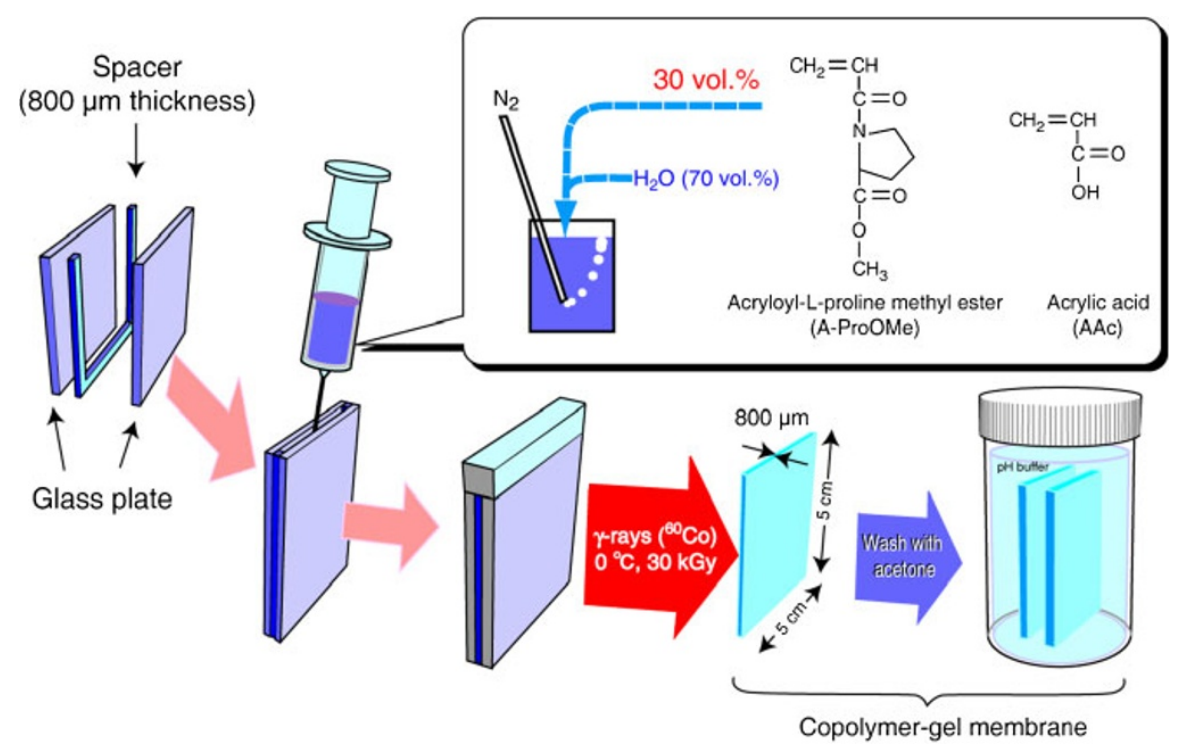

Figure 2. Schematic diagram for preparation of poly(A-ProOMe-co-AAc) gel membranes using radiation technique.

the gel membranes was sandwiched and tightly fixed with doughnuts type frosted glasses to suppress the dimensional change of the gel membranes caused by changes in $\mathrm{pH}$, temperature, and the addition of metal ions. The initial concentrations of $\mathrm{Li}, \mathrm{Co}$, and $\mathrm{Ni}$ ions in the buffer solution prepared by potassium phthalate and sodium hydroxide were $0.01 \mathrm{~mol}$. The cell set onto a stirrer (Iuchi M-3 multi-stirrer) that was immersed in a water thermostat. The mixed solutions of metal ions kept at 5 or $30^{\circ} \mathrm{C}$ were charged into the donor chamber; the eluate of $1.0 \mathrm{~mL}$ of metal ion, which permeated from the donor to the receiver chambers through the grafted gel membrane, was collected from a sampling port at various intervals. The same volume of the buffer solution was immediately added to the receiver chamber. The eluate was diluted with distilled water to adjust the solution concentrations ranging from 0.1 to $10 \mathrm{ppb}$. The concentrations of $\mathrm{Li}, \mathrm{Ni}$, and Co ions that permeated the grafted gel membranes were determined quantitatively using an inductively coupled plasma mass spectrometer (ICP-mass, Hewlett Packard 4500SERIES). Each concentration was calibrated by the supplied standard solution (ICP-Multi-element standard solution IV $(1 \mathrm{~mol} / \mathrm{L}$ $\left.\mathrm{HNO}_{3}\right)$ ) purchased from SPEX Certi Prep. Inc.

\section{Microscopic Observation}

The physical structures of thermo- and $\mathrm{pH}$-sensitive gel membranes were observed by using a scanning electron microscopy (SEM). The gel membrane with the fixed conditions of temperatures and $\mathrm{pHs}$ were immersed quickly into glass vessels previously cooled at $-85^{\circ} \mathrm{C}$, kept on more than $6 \mathrm{~h}$, and then lyophilized. ${ }^{19}$ The cross-section of the gel after coating with gold was observed with a JEOL JSM-5600 SEM. The concentration profile of $\mathrm{Co}$ and $\mathrm{Ni}$ ions bound across the thickness of the membrane, which is immersed in mixed solution of $0.01 \mathrm{mmol} \mathrm{Li}, \mathrm{Co}$, and $\mathrm{Ni}$ ions in a $\mathrm{pH} 6.0$ solution at $30^{\circ} \mathrm{C}$, were determined using an energy-dispersive $\mathrm{X}$-ray spectroscopy (EDS) (model 7388) with Oxford Instruments INCA energy.

\section{RESULTS AND DISCUSSION}

\section{The Effects of Graft Chains on Selective Permeation of $\mathbf{L i}$ Ions}

Thermo- and $\mathrm{pH}$-sensitive gel membranes were synthesized by $\gamma$-ray grafting of $\mathrm{pH}$-responsive poly acrylic acid (poly(AAc)) onto the thermo-responsive polymer gel acryloylL-proline methyl ester (A-ProOMe). In this paper, the graft degree of poly(AAc) is expressed as "X\% grafted gel membrane," where $\mathrm{X} \%$ is defined by the following equation:

$$
\begin{aligned}
& \mathrm{X} \%=100 \times \mathrm{AAc} \\
& \text { in grafted gel }(\mathrm{mol}) / \text { poly }(\mathrm{A}-\mathrm{ProOMe}) \text { gel }(\mathrm{mol})
\end{aligned}
$$

We successfully prepared three grafted gel membranes; a $5 \%$ grafted gel membrane exhibiting only thermo-sensitive volume, a $15 \%$ grafted gel membrane exhibiting both temperature and $\mathrm{pH}$ responses, and a $43 \%$ grafted gel membrane exhibiting only $\mathrm{pH}$ response.

The permeation ratios $\left(M_{\mathrm{t}} / M_{\infty}\right)$ of $\mathrm{Li}, \mathrm{Co}$, and $\mathrm{Ni}$ ions through the 5, 15, and $43 \%$ grafted gel membranes are plotted as a function of time in $\mathrm{pH} 6.0$ buffer solution at $30^{\circ} \mathrm{C}$ in Figure 3, where $M_{\mathrm{t}}$ and $M_{\infty}$ are defined as the amount of the ions permeating up to time $t$ and up to infinite time $\infty$, respectively. ${ }^{20-22}$ In those conditions, the $M_{\mathrm{t}} / M_{\infty}$ of $\mathrm{Li}$ ions through 5,15, and $43 \%$ grafted gel membranes increased with the increase of time, reaching $0.12,0.45$, and 0.58 , respectively after $10 \mathrm{~h}$. Over the same period, the $M_{\mathrm{t}} / M_{\infty}$ of Co and Ni ions reached only about one third of those of $\mathrm{Li}$ ions.

For quantitative comparison of the permeation rates of metal ions through membranes, the initial permeation constant $\left(P\left(\times 10^{-4} \mathrm{mmol} / \mathrm{L} \cdot \mathrm{min}\right)\right)$ of each metal ion is defined as the maximum penetration rate the maximum change in permeation 

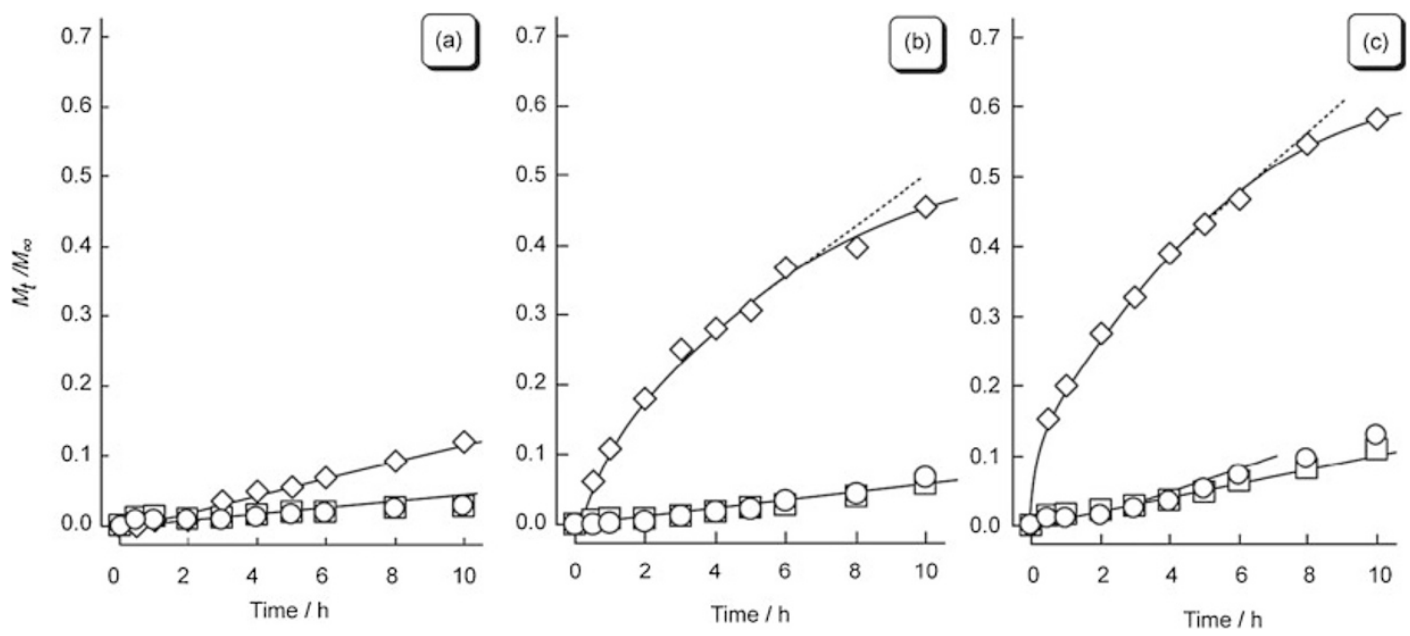

Figure 3. Plots of the permeation ratios $\left(M_{\mathrm{t}} / M_{\infty}\right)$ of $\mathrm{Li}(\diamond), \mathrm{Co}(\square)$, and $\mathrm{Ni}(\bigcirc)$ ions through the gel membranes as a function of permeation time in a pH 6.0 buffer solution at $30^{\circ} \mathrm{C}: 5 \%(\mathrm{a}), 15 \%(\mathrm{~b})$, and $43 \%$ (c) grafted gel membranes.

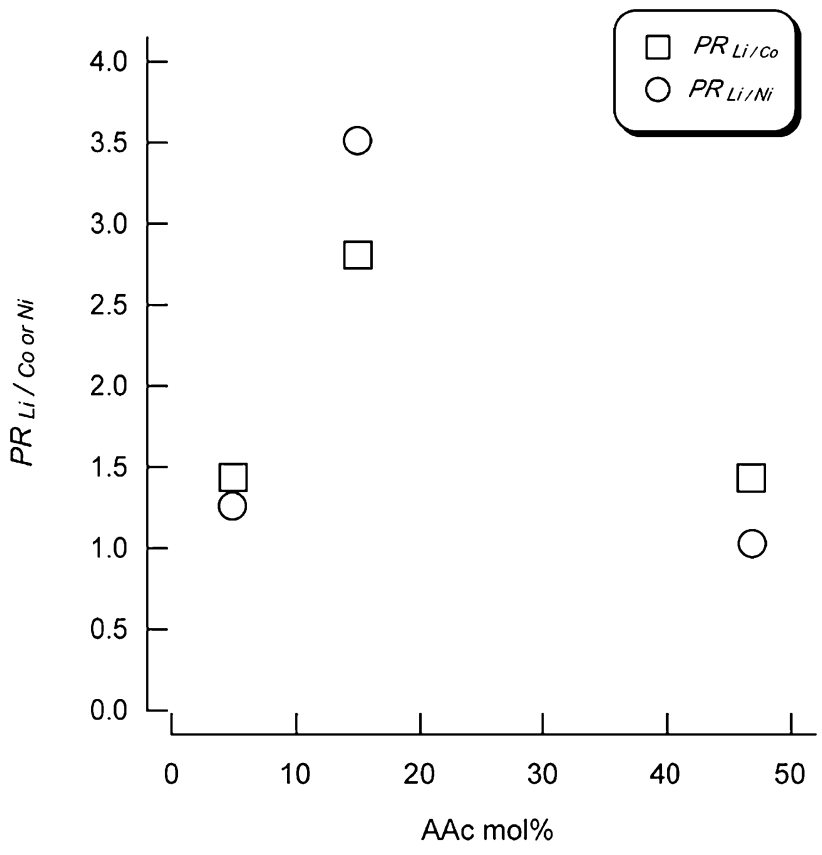

Figure 4. Plots of initial permeation rate ratios of $\mathrm{Li} / \mathrm{Co}$ ions $\left(P R_{\mathrm{Li} / \mathrm{C}}, \square\right)$ and $\mathrm{Li} / \mathrm{Co}$ ions $\left(P R_{\mathrm{Li} / \mathrm{Ni}}, O\right)$ through the gel membranes as a function of grafting degree of $\mathrm{AAc}$ in a $\mathrm{pH} 6.0$ buffer solution at $30^{\circ} \mathrm{C}$.

concentration $(\mathrm{mmol} / \mathrm{L})$ per unit of time (minutes) $\left(d M_{\mathrm{t}} / d t\right)$ max, because $M_{\mathrm{t}}$ as a function of time exhibited an induction period for all the membranes. Then, the selective $\mathrm{Li}$ ion permeability over $\mathrm{Co}$ and $\mathrm{Ni}$ ions is expressed as the permeation rate ratios of $\mathrm{Li} / \mathrm{Co}$ ions and $\mathrm{Li} / \mathrm{Ni}$ ions $\left(P R_{\mathrm{Li} / \mathrm{Co}}\right.$ and $\left.P R_{\mathrm{Li} / \mathrm{Ni}}\right)$ and are plotted as a function of $\mathrm{AAc}$ mol $\%$ in Figure 4 . The $15 \%$ grafted gel membranes showed $P R_{\mathrm{Li} / \mathrm{Co}}$ and $P R_{\mathrm{Li} / \mathrm{Ni}}$ of 2.8 and 3.5 , respectively. On the other hand, the 5 and $43 \%$ grafted gel membranes showed much smaller $P R_{\mathrm{Li} / \mathrm{Co}}$ (1.4 and 1.4) and $P R_{\mathrm{Li} / \mathrm{Ni}}$ (1.3 and 1.0) compared with the $15 \%$ grafted gel membrane. The difference is clearly explained from the results previously described in Figure 3. Namely, the permeation rates of all the metals are very low in the 5\% grafted gel membrane due to lack of ion conducting channels consisting of AAc grafts. On the contrary, $43 \%$ grafted gel membranes exhibited higher permeation rates of $\mathrm{Ni}$ and $\mathrm{Co}$ than those of $15 \%$ gel membrane, resulting in lower $P R_{\mathrm{Li} / \mathrm{Co}}$ (1.4) and $P R_{\mathrm{Li} / \mathrm{Ni}}(1.0)$. Since the $15 \%$ grafted gel membrane had greater $P R_{\mathrm{Li} / \mathrm{Co}}$ and $P R_{\mathrm{Li} / \mathrm{Ni}}, 2.8$ and 3.5, respectively, than those of 5 and $43 \%$ grafted gel membranes, the $15 \%$ grafted gel membrane was employed for the following permeation experiment.

\section{Thermo- and pH-Responses of $15 \%$ Grafted Gel Mem- brane}

The equilibrium swelling of the $15 \%$ grafted gel membrane is plotted as a function of $\mathrm{pH}$ in the range of $\mathrm{pH} 1.0-8.0$ at 5, $10,20,30$ and $60^{\circ} \mathrm{C}$ in Figure 5. In a solution with acidity fixed at $\mathrm{pH} 4.0$, the carboxyl groups of the AAc graft chains were deionized $(-\mathrm{COOH})$, and the swelling ratio of the $15 \%$ grafted gel membrane decreased from 2.5 (open circle) to 0.2 (open diamond) with increases of temperatures from 5 to $30^{\circ} \mathrm{C}$. In a pH 6.0 buffer solution, the carboxyl groups of the AAc graft chains were ionized $\left(-\mathrm{COO}^{-}\right)$, and the swelling ratio of the $15 \%$ grafted gel membrane also decreased from 8.5 (open circle) to 3.5 (open diamond) with increases of temperatures from 5 to $30^{\circ} \mathrm{C}$. With temperature fixed at $5^{\circ} \mathrm{C}$, at which the poly(A-ProOMe) moiety is in a swollen state, the volume ratios in the $15 \%$ grafted gel membrane increased from 2.5 to 8.5 with increases of the acidity from $\mathrm{pH} 4.0$ to 6.0. In a buffer solution at $30^{\circ} \mathrm{C}$, at which the poly(A-ProOMe) moiety is in a shrunken state, the volume ratios of the $15 \%$ grafted gel membrane increased from 0.22 to 3.5 with increases of the acidity from $\mathrm{pH} 4.0$ to 6.0. It is clear from above observations that the volume of the $15 \%$ grafted gel membrane can be controlled by changing in temperature and $\mathrm{pH}$ of the buffer solution. The $\mathrm{pH}$ break points, above which the gel membranes start swelling, were shifted from $\mathrm{pH} 4.5$ to 5.0 when the gel membranes placed above $30^{\circ} \mathrm{C}$. This shift should result from 


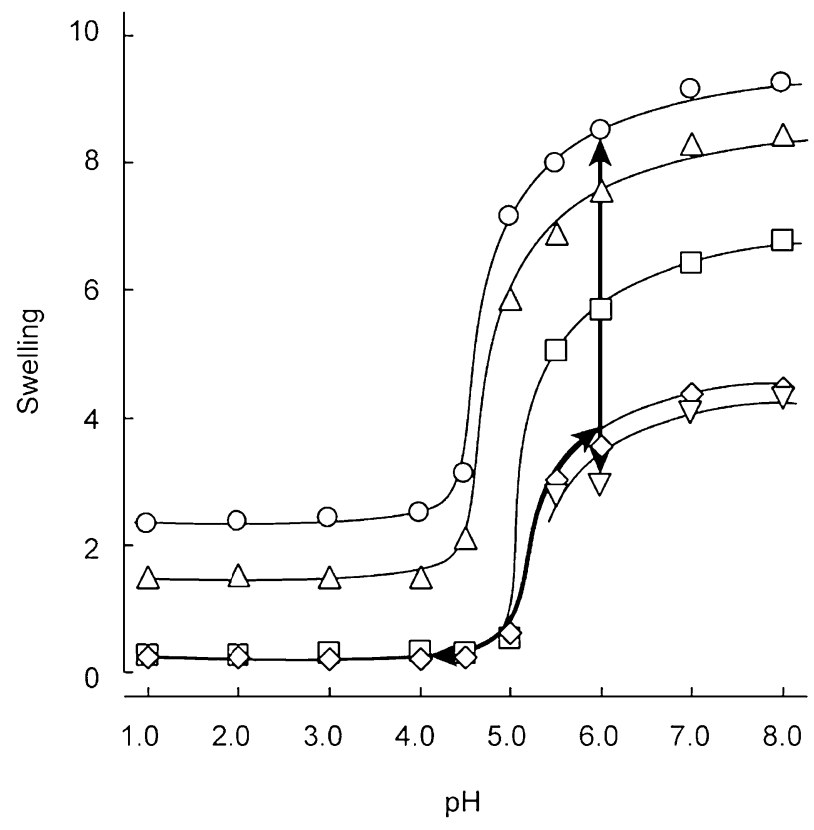

Figure 5. The equilibrium swelling of the $15 \%$ poly(A-ProOMe)-graft-poly(AAc) gel membrane as a function of $\mathrm{pH}$ in the range of $\mathrm{pH} 1.0$ 9.0 at the temperatures of $5^{\circ} \mathrm{C}(\bigcirc), 10^{\circ} \mathrm{C}(\triangle), 20^{\circ} \mathrm{C}(\square), 30^{\circ} \mathrm{C}$ $(\diamond)$, and $60^{\circ} \mathrm{C}(\nabla)$.

the suppress of swelling in ionizing poly(AAc) moiety surrounded by the deswollen thermo-responsive (A-ProOMe) moiety.

\section{Thermo- and pH-Effects of Permeation of Li Ions through} the $15 \%$ Gel Membrane

The selective Li ion permeability over Co and $\mathrm{Ni}$ ions of the $15 \%$ grafted gel membrane, $P R_{\mathrm{Li} / \mathrm{Co}}$ and $P R_{\mathrm{Li} / \mathrm{Ni}}$ were plotted in Figure 6 as functions of temperature in the fixed acidity of $\mathrm{pH}$ 6.0. At $5{ }^{\circ} \mathrm{C}$ in the $\mathrm{pH} 6.0$ buffer solution, in which both thermo-responsive A-ProOMe membranes and $\mathrm{pH}$ responsive poly(AAc) were in swollen states, the selective $\mathrm{Li}$ ion permeability over $\mathrm{Co}$ and $\mathrm{Ni}$ ions through the membranes were not very high $\left(P R_{\mathrm{Li} / \mathrm{Co}}=2.2\right.$ and $\left.P R_{\mathrm{Li} / \mathrm{Ni}}=1.1\right)$. When the temperature increased to $30^{\circ} \mathrm{C}$, at which the thermoresponsive unit deswelled and the $\mathrm{pH}$ responsive unit remains to swell, the selectivity of $\mathrm{Li}$ permeation increased to $P R_{\mathrm{Li} / \mathrm{Co}}=2.8$ and $P R_{\mathrm{Li} / \mathrm{Ni}}=3.5$. However, at $60^{\circ} \mathrm{C}$, the membrane, which has the same swollen and deswollen structures as that at $30^{\circ} \mathrm{C}$, showed lower $P R_{\mathrm{Li} / \mathrm{Co}}$ and $P R_{\mathrm{Li} / \mathrm{Ni}}$ (0.84 and 0.87 ) than those at $30^{\circ} \mathrm{C}$. The trend of the $P R_{\mathrm{Li} / \mathrm{Co}}$ and $P R_{\mathrm{Li} / \mathrm{Ni}}$ values of the $15 \%$ grafted gel membranes at 5 and $30{ }^{\circ} \mathrm{C}$ seems to be reverse order to each other in Figure 6. However, this is probably due to the very low permeation rates ( 0.84 and $0.87 \mathrm{mmol} / 1 \mathrm{~min}$ ) at $60{ }^{\circ} \mathrm{C}$. On the other hand, similar $P R_{\mathrm{Li} / \mathrm{Co}}$ and $P R_{\mathrm{Li} / \mathrm{Ni}}$ values of the $15 \%$ grafted gel membrane at $5{ }^{\circ} \mathrm{C}$ can be explained by the fact that the permeation rates of both $\mathrm{Ni}$ and $\mathrm{Co}$ ions are too high to show a selective $P R$ to each other, resulting in more error values at $5{ }^{\circ} \mathrm{C}$.

Figure 7 shows the plots of $P R_{\mathrm{Li} / \mathrm{Co}}$ and $P R_{\mathrm{Li} / \mathrm{Ni}}$ as functions of $\mathrm{pH}$ at the fixed temperature of $30^{\circ} \mathrm{C}$. The selective $\mathrm{Li}$ ion

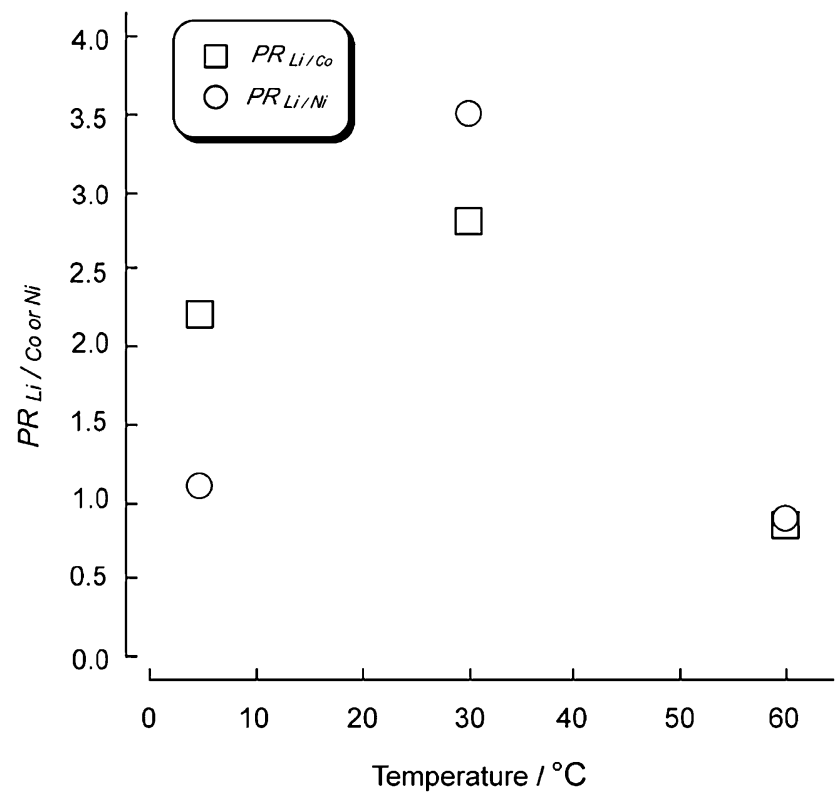

Figure 6. Plots of initial permeation rate ratios of $\mathrm{Li} / \mathrm{Co}$ ions $\left(P R_{\mathrm{Li} / \mathrm{Co}}, \square\right)$ and $\mathrm{Li} / \mathrm{Ni}$ ions $\left(P R_{\mathrm{Li} / \mathrm{Ni}}, O\right)$ of $15 \%$ grafted gel membranes as a function of temperature in a $\mathrm{pH} 6.0$ buffer solution.

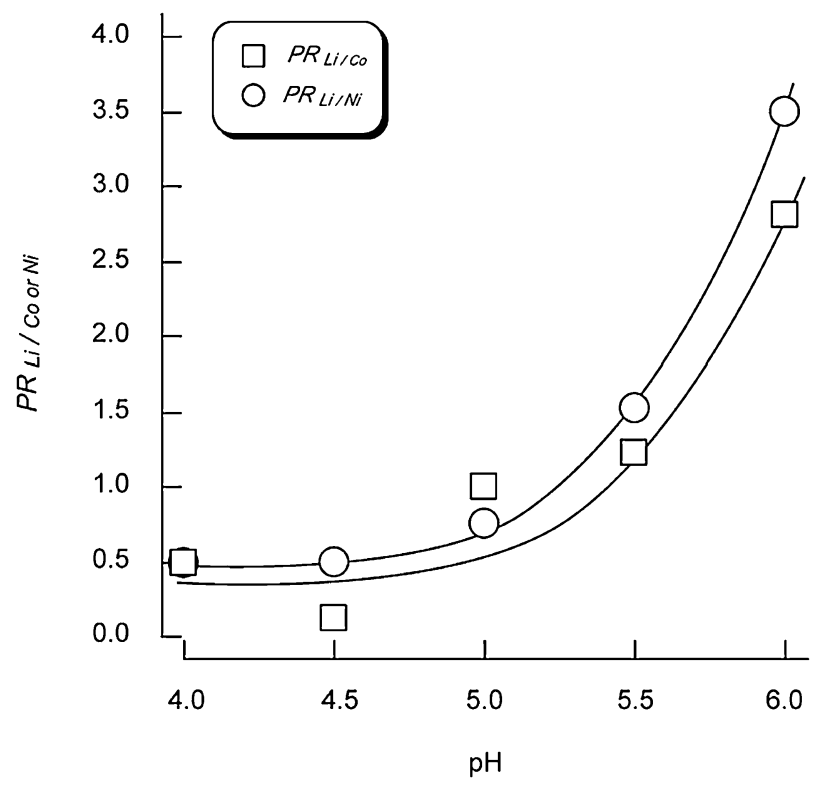

Figure 7. Plots of permeation rate ratios of $\mathrm{Li} / \mathrm{Co}$ ions $\left(P R_{\mathrm{Li} / \mathrm{Co}}, \square\right)$ and $\mathrm{Li} / \mathrm{Ni}$ ions $\left(P R_{\mathrm{Li} / \mathrm{Ni}}, O\right)$ of $15 \%$ grafted gel membranes as a function of $\mathrm{pH}$ at $30^{\circ} \mathrm{C}$

permeability over $\mathrm{Co}$ and $\mathrm{Ni}$ ions $\left(P R_{\mathrm{Li} / \mathrm{Co}}\right.$ and $\left.P R_{\mathrm{Li} / \mathrm{Ni}}\right)$ at $\mathrm{pH} 4.0$ were 0.50 and 0.50 , respectively. When the $\mathrm{pH}$ of the buffer solution increased to $\mathrm{pH} 6.0, P R_{\mathrm{Li} / \mathrm{Co}}$ and $P R_{\mathrm{Li} / \mathrm{Ni}}$ increased gradually and reached to 2.8 and 3.5 at $\mathrm{pH} 6.0$, at which the thermo-responsive unit deswelled and the $\mathrm{pH}$ responsive unit swelled, respectively. Unfortunately, the membranes are not mechanically strong enough in the $\mathrm{pH}$ above 7.0. Consequently, it is clear that the optimal condition for the selective permeation of $\mathrm{Li}$ ions through the $15 \%$ grafted gel membrane were at $30^{\circ} \mathrm{C}$ in a $\mathrm{pH} 6.0$ buffer solution. 
Table I. Permeation constants $(P)$ and permeation constant ratios $(P R)$ of PE-graft-poly(AAc) and poly(A-ProOMe-co-AAc) gel membranes $\left(P: \times 10^{-4} \mathrm{mmol} / \mathrm{L} \cdot \mathrm{min}\right)$

\begin{tabular}{cccccc}
\hline & \multicolumn{3}{c}{ Permeation constants } & \multicolumn{2}{c}{ Permeation constant ratios } \\
\cline { 2 - 6 } & $P_{\mathrm{Li}}$ & $P_{\mathrm{Co}}$ & $P_{\mathrm{Ni}}$ & $P R_{\mathrm{Li} / \mathrm{Co}}$ & $P R_{\mathrm{Li} / \mathrm{Ni}}$ \\
\hline PE-graft-poly(AAc) & 4.0 & 1.9 & 1.4 & 2.1 & 2.9 \\
poly(A-ProOMe-co-AAc) & 5.2 & 3.9 & 3.4 & 1.3 & 1.5 \\
\hline
\end{tabular}

\section{Effect of Thermo-responsive Matrix and $\mathrm{pH}$ Sensitive Grafted Chain Structures}

The effect of thermo-responsive poly(A-ProOMe) gel matrix on the selective $\mathrm{Li}$ ion permeability over $\mathrm{Co}$ and $\mathrm{Ni}$ ions through the grafted gel membrane should be evaluated by comparing the selective permeation characters with the membranes consisting of AAc graft chains on porous polyethylene membranes (PE-graft-poly(AAc)) that are not thermoresponsive. $74 \%$ grafted $\mathrm{PE}$ - graft-poly(AAc) was synthesized by grafting AAc onto PE porous film because the $74 \%$ grafted membranes shows almost the same initial permeation rate of $\mathrm{Li}$ ions $\left(4.0 \times 10^{-4} \mathrm{~min}^{-1}\right)$ as that of $15 \%$ poly(A-ProOMe)-graftpoly(AAc) $\left(5.6 \times 10^{-4} \mathrm{~min}^{-1}\right)$. The selective $\mathrm{Li}$ ion permeability over $\mathrm{Co}$ and $\mathrm{Ni}$ ions through $\mathrm{PE}$-graft-poly(AAc) membrane $\left(P_{\mathrm{Li}}=4.0\right)$ at $30^{\circ} \mathrm{C}$ in $\mathrm{pH} 6.0$ buffer solutions was higher than those of $\mathrm{Co}\left(P_{\mathrm{Co}}=1.9\right)$ and $\mathrm{Ni}\left(P_{\mathrm{Ni}}=1.4\right)$, respectively (Table I). However, the selective $\mathrm{Li}$ ion permeability over $\mathrm{Co}$ and $\mathrm{Ni}$ ions, $P R_{\mathrm{Li} / \mathrm{Co}}(2.1)$ and $P R_{\mathrm{Li} / \mathrm{Ni}}(2.9)$ of the PE grafted membrane were lower than those of the $15 \%$ grafted gel membrane (about 80\%). Accordingly, the thermoresponsive poly(A-ProOMe) makes a condition to the selective permeation of $\mathrm{Li}$ ions over $\mathrm{Co}$ and $\mathrm{Ni}$ ions.

Next, we investigated the effect of the AAc configuration in the gel membranes (block and random structures) on the selective Li ion permeability over $\mathrm{Co}$ and $\mathrm{Ni}$ ions. A random copolymer gel membrane, in which $15 \%$ AAc are dispersed in a main chain of poly(A-ProOMe), were synthesized; then, the selective $\mathrm{Li}$ ion permeability over $\mathrm{Co}$ and $\mathrm{Ni}$ ions $\left(P R_{\mathrm{Li} / \mathrm{Co}}\right.$ and $\left.P R_{\mathrm{Li} / \mathrm{Ni}}\right)$ were compared with those of the $15 \%$ grafted poly(A-ProOMe)-graft-poly(AAc). The random copolymer gel membrane of AAc and A-ProOMe (poly(A-ProOMe-coAAc)) was synthesized at $0^{\circ} \mathrm{C}$ for $3 \mathrm{~h}$ at a dose rate of $10 \mathrm{kGy} / \mathrm{h}$, using $\gamma$-rays from a ${ }^{60} \mathrm{Co}$ source. The permeation of Li ions $\left(P_{\mathrm{Li}}\right)$ through poly(A-ProOMe-co-AAc) gel membrane in a pH 6.0 buffer solutions at $30^{\circ} \mathrm{C}$ was 5.2 , which is slightly higher than those of $\mathrm{Co}$ and $\mathrm{Ni}$ ions (3.9 and 3.4) (Table). However, the selective $\mathrm{Li}$ ion permeability over $\mathrm{Co}$ and $\mathrm{Ni}$ ions $P R_{\mathrm{Li} / \mathrm{Co}}$ (1.3) and $P R_{\mathrm{Li} / \mathrm{Ni}}$ (1.5) of the copolymer were only 37$53 \%$ of those of the $15 \%$ grafted gel membrane. In general, a block-type graft copolymer retains the chemical and physical properties of the corresponding homopolymers, while random co-polymers exhibit the different properties of each homopolymer. ${ }^{6}$ Accordingly, the branched structure of the carboxyl groups of poly(AAc) surrounded by thermo-response AProOMe matrix is required for the selective interactions with $\mathrm{Co}$ and $\mathrm{Ni}$, resulting in faster ion permeability of $\mathrm{Li}$ over $\mathrm{Co}$ and $\mathrm{Ni}$ ions.
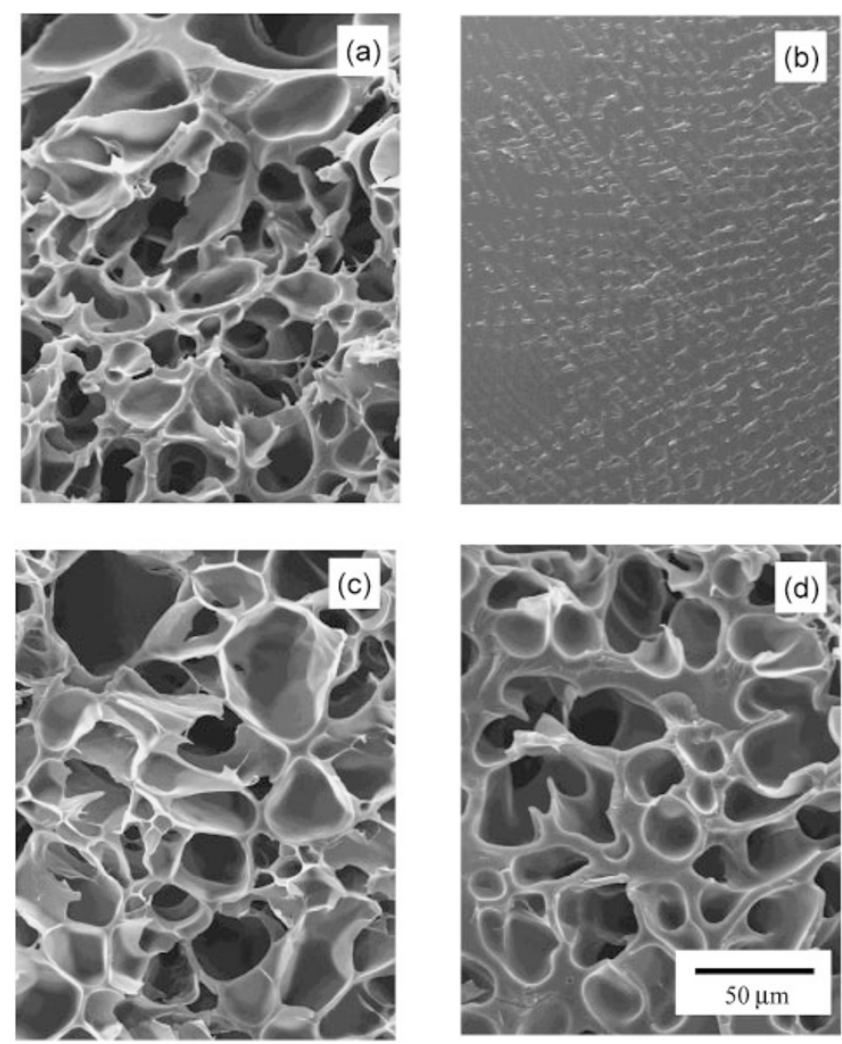

Figure 8. Cross-sectional SEM photographs of $15 \%$ poly(A-ProOMe)-graftpoly $(\mathrm{AAc}) \mathrm{gel}$ membranes at various conditions; $5^{\circ} \mathrm{C} / \mathrm{pH} 4.0$ (a), $30^{\circ} \mathrm{C} / \mathrm{pH} 4.0$ (b), $5^{\circ} \mathrm{C} / \mathrm{pH} 6.0$ (c), and $30^{\circ} \mathrm{C} / \mathrm{pH} 6.0$ (d).

\section{Microscopic Structures Observed by SEM}

To find the relation between micro porous structures of gel membranes and the selective permeability of $\mathrm{Li}$ ions, the microscopic network structures in the grafted gel membranes were investigated using a scanning electron microscopy (SEM). The cross-sectional photographs of the gel membranes $\mathrm{A}, \mathrm{B}, \mathrm{C}$, and $\mathrm{D}$, which were kept under the conditions $5^{\circ} \mathrm{C} /$ $\mathrm{pH} 4.0,30^{\circ} \mathrm{C} / \mathrm{pH} 4.0,5^{\circ} \mathrm{C} / \mathrm{pH} 6.0$, and $30^{\circ} \mathrm{C} / \mathrm{pH} 6.0$, and then lyophilized, are shown in Figure 8(a)-(d). The A-ProOMe matrix and AAc graft chains of gel membranes A, B, C, and D are in the swollen/shrunken, shrunken/shrunken, swollen/ swollen, and shrunken/swollen states, respectively. The gel membrane $\mathrm{B}$ found in a $\mathrm{pH} 4.0$ buffer solution at $30^{\circ} \mathrm{C}$ dose not show any metal permeation selectivity, due to complete shrinkage of both matrix and grafted chains, as shown in Figure 8(b). The gel membrane $\mathrm{C}$ formed in a $\mathrm{pH} 6.0$ buffer solution at $5{ }^{\circ} \mathrm{C}$, which exhibits less metal ion permeation selectivity, has thinner walls and larger pore size, as shown in Figure 8(c). The micro-structure of the gel membranes A and D are similar to each other; both membranes have thick walls with pores. The porous structure in the gel membrane A should consist of the shrunken poly(AAc) graft chains as a thick wall (about $2.1 \mu \mathrm{m}$ ), whereas that in the gel membrane D should consist of the shrunken A-ProOMe matrix as a thick wall (about $6.4 \mu \mathrm{m}$ ). These gel structure observations strongly suggest that the gel micro-structure consisting of ion channels 


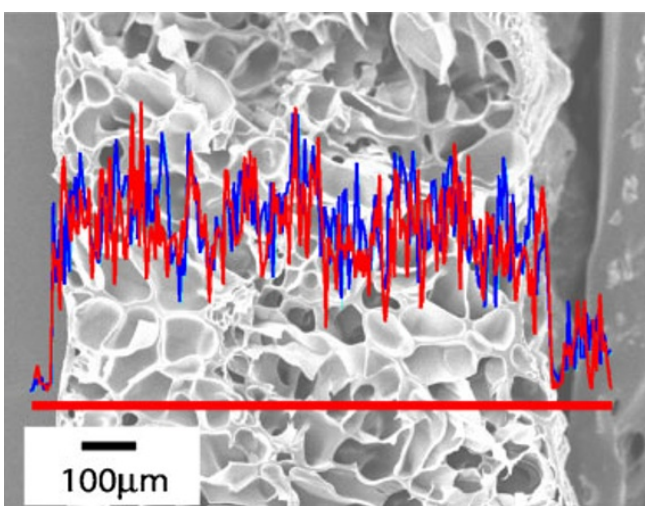

Figure 9. EDS profiles of $\mathrm{Co}$ and $\mathrm{Ni}$ ions across the $15 \%$ poly(A-ProOMe)graft-poly $(\mathrm{AAc})$ gel membrane after $10 \mathrm{~h}$ of permeation experiment in a $\mathrm{pH} 6.0$ buffer solution at $30^{\circ} \mathrm{C}$ (Red line: $\mathrm{Co}$, Blue line: $\mathrm{Ni}$ ).

of poly(AAc) grafted chains separated by a thicker wall of AProOMe is a favorable for the selective permeation of metal ions.

When we continued permeation experiments of the of $\mathrm{Li}, \mathrm{Co}$ and $\mathrm{Ni}$ ions through the $15 \%$ poly(A-ProOMe)-graft-poly(AAc) gel membrane in a $\mathrm{pH} 6.0$ buffer solution at $30^{\circ} \mathrm{C}$, the permeation of $\mathrm{Li}$ ions started immediately after the beginning of the experiment and achieved equilibrium at $24 \mathrm{~h}$. In contrast, the permeation of $\mathrm{Co}$ and $\mathrm{Ni}$ ions exhibited an induction period of $2 \mathrm{~h}$ and the permeation rates of these metal ions did not level off even after $60 \mathrm{~h}$. Figure 9 shows the distributions of Co and $\mathrm{Ni}$ ions along the cross section of the graft gel membrane, which was measured by the line scan of an energy-dispersive $\mathrm{X}$-ray spectroscopy (EDS), after $10 \mathrm{~h}$ of permeation. Co and $\mathrm{Ni}$ ions were distributed along the cross section of the membrane from the source to the receiver sides, as shown in Figure 9. The concentration profile of $\mathrm{Co}$ and $\mathrm{Ni}$ ions is not homogeneous, since the permeation rate should be zero. However, the concentration gradient of the metal ions in the membranes should be too small to be detected by SEM-EDS measurement.

On the basis of the above results, the Li-selective permeation can be interpreted as follows. The induction period observed for only $\mathrm{Ni}$ and $\mathrm{Co}$ ions results from the larger interactions of $\mathrm{Ni}$ and $\mathrm{Co}$ ions with the carboxylic groups in the grafting chains compared with that of $\mathrm{Li}$ ions. Co and $\mathrm{Ni}$ ions form complexes with carboxylate anions of the acrylic acidgrafted chains in the $15 \%$-grafted membrane just after the permeation. It is well known that the multi functional carboxylic acids have strong affinity to polyvalent metal ions such as Co and Ni than monovalent one even though acetic acid does not show such selectivity. ${ }^{23}$ For example, ETDA, which has four carboxylic acids, shows 16.3 and 18.6 of binding constants with $\mathrm{Co}$ and $\mathrm{Ni}$, which is much higher than that with $\mathrm{Li}$ (2.8). ${ }^{23}$ By taking account of the results that block but random copolymer gel membrane can exhibit selective permeation of Li ions, adjacent carboxyl groups of poly(AAc) on the thermo-responsive walls can make suitable conformation to interact with $\mathrm{Co}$ and $\mathrm{Ni}$ ions by the four coordinate structure. The pore sizes of ion channels $(21-35 \mu \mathrm{m})$ of
poly(AAc) graft chains constructed by the A-ProOMe walls are much larger than the diameters of hydrated $\mathrm{Co}$ and $\mathrm{Ni}$ ions $(0.4 \mathrm{~nm})$. Thus, it is obvious that the pore and wall structures constructed by $\mathrm{pH}$ and thermo-responsive polymers are not suitable for size recognition of hydrated metal ions but allow the poly(AAc) graft chains on the A-ProOMe walls to take suitable conformation to interact with $\mathrm{Co}$ and $\mathrm{Ni}$ ions by the four coordinate structure.

$\mathrm{Co}$ and $\mathrm{Ni}$ ions gradually diffuse into the membrane and after $2 \mathrm{~h}$, they start permeating through the other side of membrane and the complexation reaches equilibrium. After this equilibrium state, the $\mathrm{Co}$ and $\mathrm{Ni}$ ions slowly permeate through, repeating dissociation and complexation with carboxylate ions along a graft chain or between graft chains. On the other hand, Li ions can permeate quickly without the complexation with carboxyl anions. As a result, the selective permeation of $\mathrm{Li}$ over $\mathrm{Co}$ and $\mathrm{Ni}$ ions through the $15 \%$ grafted gel membrane can be achieved in a $\mathrm{pH} 6.0$ buffer solution at $30^{\circ} \mathrm{C}$.

\section{CONCLUSIONS}

We investigated the permeation behavior of $\mathrm{Li}, \mathrm{Co}$, and $\mathrm{Ni}$ ions through thermo- and $\mathrm{pH}$-responsive gel membranes. The gel membranes were synthesized by $\gamma$-ray grafting of $\mathrm{pH}$ responsive poly(acrylic acid) (AAc) onto a thermo-responsive polymer gel of acryloyl-L-proline methyl ester (A-ProOMe). Using 15\% AAc grafted membrane, the permeation constant of $\mathrm{Li}$ ions through the membrane is 3.5 and 2.8 times higher than those of $\mathrm{Co}$ and $\mathrm{Ni}$ ions in a $\mathrm{pH} 6.0$ buffer solution at $30^{\circ} \mathrm{C}$. These ratios are two and three times higher than those of 5 or $43 \%$ grafted gel membranes, respectively. By comparison with the permeation of metal ions through the grafted membranes consisting of AAc graft chains on porous polyethylene membranes (PE-graft-poly(AAc)) that are not thermo-responsive as well as that of a random copolymer gel (poly(AProOMe-co-AAc)), it is clear that both adjacent chains of the block structure, in which the carboxyl groups of poly(AAc) surround by thermo-responsive A-ProOMe matrix appear be essential for the selective $\mathrm{Li}$ ion permeability over $\mathrm{Co}$ and $\mathrm{Ni}$ ions. From the microscopic structures in the gel membranes (SEM) and the distributions of $\mathrm{Co}$ and $\mathrm{Ni}$ ions (EDS), we confirmed that the gel structures formed by the flexible grafted chains of the carboxyl groups onto the thermo-response gel membrane play a decisive role for the selective permeation of $\mathrm{Li}$ over $\mathrm{Co}$ and $\mathrm{Ni}$ ions.

Received: November 22, 2007

Accepted: March 19, 2009

Published: May 13, 2009

\section{REFERENCES}

1. F. Martellini, O. Z. Higa, E. Takacs, A. Safranji, M. Yoshida, R. Katakai, and M. Carenza, Radiat. Phys. Chem., 55, 185 (1999).

2. M. Yoshida, A. Safranji, H. Omichi, and R. Katakai, Radiat. Phys. Chem., 46, 1053 (1995). 
3. J. Chen, S. Hasegawa, H. Ohashi, Y. Maekawa, M. Yoshida, R. Katakai, and N. Tsubokawa, Macromol. Rapid Commun., 23, 141 (2002).

4. R. Yoshida, K. Sakai, T. Okano, and Y. Sakurai, Adv. Drug Delivery Rev., 11, 85 (1993).

5. Y. Osada, H. Okuzaki, and H. Hori, Nature, 355, 242 (1992).

6. S. Hasegawa, H. Ohashi, Y. Maekawa, R. Katakai, and M. Yoshida, Radiat. Phys. Chem., 72, 595 (2005).

7. A. Hiroki, Y. Maekawa, M. Yoshida, and R. Katakai, Polymer, 42, 6403 (2001).

8. N. Nagaoka, A. Safranj, M. Yoshida, and H. Omichi, Macromolecules, 26, 7386 (1993).

9. M. Yoshida, A. Safranj, and H. Omichi, Macromolecules, 29, 2321 (1996).

10. G. Chen and A. S. Hoffman, Macromol. Rapid Commun., 16, 175 (1995).

11. M. Higa and T. Yamakawa, J. Phys. Chem. B, 108, 16703 (2004).

12. M. Yoshida, A. Safranj, H. Omichi, M. Miyajima, and R. Katakai, Radiat. Phys. Chem., 46, 181 (1995).
13. M. Yoshida, H. Omichi, H. Kubota, and R. Katakai, J. Intell. Mater. Syst. Struct., 4, 223 (1993).

14. J. Hendri, A. Hiroki, Y. Maekawa, M. Yoshida, and R. Katakai, Radiat. Phys. Chem., 60, 617 (2001).

15. M. Yoshida, H. Omichi, and R. Katakai, Eur. Polym. J., 28, 1141 (1992).

16. S. Tsuneda, K. Saito, S. Furusaki, and T. Sugo, J. Chromatogr., A, 689, 211 (1995).

17. M. Kim and K. Saito, Radiat. Phys. Chem., 57, 167 (2000).

18. T. J. Franz, J. Invest. Dermatol., 64, 190 (1975).

19. N. Kato and F. Takahashi, Bull. Chem. Soc. Jpn., 70, 1289 (1997).

20. M. Yoshida, M. Asano, T. Suwa, and R. Katakai, Radiat. Phys. Chem., 55, 677 (1999).

21. M. T. am Ende and N. A. Peppas, J. Controlled Release, 48, 47 (1997).

22. W. Lee and R. Chiu, J. Appl. Polym. Sci., 86, 1592 (2002).

23. A. Ringbom, "Complexation in Analytical Chemistry," John Wiley and Sons Inc., New York, 1963. 